\title{
Sustainability of Cultural Heritage in World Heritage Site, Melaka
}

\author{
Nur Izzati Mohd Rodzi, Saniah Ahmad Zaki, \\ Syed Mohd Hassan Syed Subli \\ Faculty of Architecture, Planning \& Surveying, \\ Universiti Teknologi MARA, 40450 Shah Alam, Malaysia \\ Nurizzatirodzi@gmail.com
}

\begin{abstract}
Cultural heritage is constructed from the intrinsic relationship between three fundamentals: society; tangible cultural heritage (TCH); and intangible cultural heritage (ICH). To sustain, cultural heritage relies on the social behaviour of society. Thus, reflecting fragility of heritage. Hence, this paper attempts to discourse the society's behaviour towards $\mathrm{ICH}$. Exploratory case study was employed by adapting five social behaviour related-criterions required by UNESCO. The data was analysed using two techniques: (1) simple statistical; and (2) thematic. The results indicate that the status of ICH is threatened due to the weak viability level and minimal safeguarding effort by the 'society'.
\end{abstract}

Keywords: social behaviour; intangible cultural heritage; world heritage site, threatened

eISSN: 2398-4295 @ 2016. The Authors. Published for AMER ABRA by e-International Publishing House, Ltd., UK.. This is an open access article under the CC BY-NC-ND license (http://creativecommons.org/licenses/by-ncnd/4.0/). Peer-review under responsibility of AMER (Association of Malaysian Environment-Behaviour Researchers), ABRA (Association of Behavioural Researchers on Asians) and cE-Bs (Centre for EnvironmentBehaviour Studies), Faculty of Architecture, Planning \& Surveying, UniversitiTeknologi MARA, Malaysia.

https://doi.org/10.21834/ajbes.v1i4.43 


\subsection{Introduction}

Cultural heritage is a symbiotic relationship involving society, norms and values. These are the pillars, the triangle relationship to form a smart partnership to sustain cultural heritage (Munjeri, 2004). On the other hand, symbols, technologies and objects are tangible evidence of fundamental norms and values (Bouchenaki, 2003). This two (2) statements show the inevitable association between Tangible Cultural Heritage (TCH) and Intangible Cultural Heritage (ICH) in envisioning the cultural shape and significance towards the community or society. The characteristic of $\mathrm{ICH}$ that relies on $\mathrm{TCH}$ and the possessors reflects the vulnerability of the elements. As the conservation of TCH is positively achieved, the effort of safeguarding $\mathrm{ICH}$ seems missing. The finding in a study by Othman and Hamzah (2013) has confirmed that the preservation and safeguarding effort of $\mathrm{ICH}$ is less emphasized in the MWHS. Figure 1 is an illustration on the association of the individual, community, and society, with cultural heritage. These components are important variables of this research.

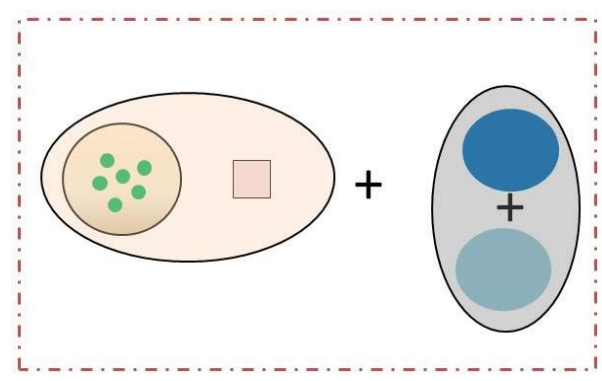

Legend:



Figure 1.1 Associations of Components in Cultural Heritage

Melaka nominated, as World Heritage Site on 2008, comprises of three (3) criteria of Outstanding Universal Values (OUV). One of the criterions is concerning Melaka as the most complete surviving historic cities in the Straits of Malacca with a multi-cultural living heritage originating from the trade routes at that time (ICOMOS, 2008). The term 'living heritage' as stated in the justification of the OUV criteria (criterion iii) is a proof of the extraordinary and unique existence of $\mathrm{ICH}$ value on the site. Therefore, this paper intends to discourse the society behaviour against ICH at Core Zone, Melaka World Heritage Site. The research questions, firstly, what the subsist ICH in the study area, and secondly, what the status of $\mathrm{ICH}$ within the study area. 


\subsection{Methodology}

Research methodology is important to determine the research idea and concept that is worth pursuing (Congdon \& Dunham, 1999). Therefore, to achieve the aim of this research, researchers set up three (3) mechanisms in its methodology. The mechanisms are: 1) research approach; 2) research instrument and 3) data analysis procedure. In order to achieve the research aim, adaptation of five (5) criterions ( 4 of the criterions are related to social-behaviour) required by UNESCO, as stated in 'Urgent Safeguarding List' is necessary to be included in each stage of the methodology. These criterions later used as indicator in $\mathrm{ICH}$ status evaluation in the analysis stage. The five (5) criterions are:

- Criterion 1 - The element constitutes Intangible Cultural Heritage as defined in Article 22 of the Convention

- $\quad$ Criterion 2 - a) The element is in urgent need of safeguarding because its viability is at risk despite the efforts of the community, group or, if applicable, individuals and State(s) Party(ies) concerned; (or) b) The element is in extremely urgent need of safeguarding because it is facing grave threats as a result of which it cannot be expected to survive without immediately safeguarding.

- Criterion 3 - Safeguarding measures are elaborated that may enable the community, group or, if applicable, individuals concerned to continue the practice and transmission of the element

- Criterion 4 - The element has been nominated following the widest possible participation of the community, group or, if applicable, individuals concerned and their free, prior and informed consent.

- Criterion 5 - The element is included in an inventory of the intangible cultural heritage present in the territory (ies) of the submitting State(s) Party (ies), as defined in Article 113 and Article 124.

\subsection{Research Approach}

The first component of research approach is case study oriented research. The researchers decided to employ exploratory case study because this type best describes a study that attempts to understand what happen within the case by looking beyond descriptive features and investigate surrounding context (CAPAM, 2010). The second research approach is utilization of the mixed method. This method was applied in the field of the cultural anthropologist as well as the sociologist for the first 60 years of the 20th century (Johnson, Onwuegbuzie, \& Turner, 2007).

\subsection{Research Instrument}

Research instrument is a mechanism to elicit data needed as determined in the preliminary stage of research design. The importance of research instrument is to ensure information obtained fulfill the research data requirement. There are three (3) types of data instrument utilized in this research, which are: 
- $\quad$ Site observation and inventory which are attempted to fulfill the criterion 1.

- Face to face questionnaire survey designed to achieve the criterion 2, 3 and 4.

- $\quad$ Structured professional interview is designed to achieve the criterion 5

\subsection{Data Analysis Procedure}

Data analysis will assist to support and answer the research questions. Therefore, there are two (2) types of data analysis procedure engaged in this research. The data procedures are: 1) frequency distribution and cross tabulation by using SPSS; and 2) thematic analysis.

\subsection{Research Limitation}

Limitation according to Simon and Goes (n.d) are matters that emerge in the research, which is beyond the researcher's control. The limitations occurred in this research were: 1) inconsistency responses by targeted respondents; 2) limited professionals' involvement during data collection phases; and 3) time-constraints.

\subsection{Results}

\subsection{Criterion 1 - Identification of the Subsist ICH}

Based on the site observation and inventory, there are 815 buildings (including lots) available in the research area. From the statistical analysis, $599(73.5 \%)$ buildings out of 815 are occupied, 32 (3.9\%) buildings are under renovation and $184(22.6 \%)$ buildings are vacant. From the overall building uses and activities, Table 3.1 shows three (3) identified domains subsist in the research area.

Table 3.1 Subsist ICH Domain in the Research Area

\begin{tabular}{lcc}
\hline \multicolumn{1}{c}{ Domain } & Details & \multicolumn{1}{c}{ Justification } \\
\hline $\begin{array}{l}\text { Traditional } \\
\text { craftsmanship }\end{array}$ & 20 practitioners & $\begin{array}{c}\text { All the practitioners treasure skills and knowledge in specific } \\
\text { craftsmanship. These skills are precious as they have been } \\
\text { transmitted for generations and influence the formation of } \\
\text { community identity as well as physical development. }\end{array}$ \\
\hline $\begin{array}{l}\text { Social practice, ritual } \\
\text { and festive events }\end{array}$ & $\begin{array}{c}22 \text { religious } \\
\text { purpose specific } \\
\text { building }\end{array}$ & $\begin{array}{c}\text { This public and private religious purposes building proves the } \\
\text { multicultural community norm and belief that linger for hundreds } \\
\text { of years }\end{array}$ \\
\hline $\begin{array}{l}\text { Knowledge and } \\
\text { practice concerning } \\
\text { nature and universe }\end{array}$ & $\begin{array}{c}\text { 14 Traditional } \\
\text { trade }\end{array}$ & $\begin{array}{c}\text { All of the streets in core zone embody unique identity. } \\
\text { Throughout the observation, Kg Pantai Street remains the } \\
\text { significant identity as a trade centre. The activities of 'go-down' } \\
\text { and wholesale remains until today. }\end{array}$ \\
\hline
\end{tabular}

\subsection{Criterion 2 - indication of viability level}

For criterion 2, the analysis has narrowed down to the only effected domains. At this point criterion 2 aims to measure viability of each domain. This viability measure is to identify the ability of domains to live or to operate by themselves. To identify the level of viability, the 
researchers have framed six (6) questions. These questions are important to reflect the possibilities of the $\mathrm{ICH}$ to sustain and practice. Table 3.2 shows a summary of frequency distribution of viability measure for two $\mathrm{ICH}$ domains. This indication is only significant to the practitioners of traditional craftsmanship, and knowledge and practice domains. Researchers were incapable to cover the aspects of social practice, rituals and festive events domain due to time constraints and limitations. From the overall data revealed, the issues confront by the Traditional Craftsmanship domain outweigh the issues in the knowledge and practice domain. The issues are;

- Irregularity of practice - Majority of Traditional Craftsmanship practitioners only practiced when requested.

- Lacking of demand and unprofitable product - Besides irregularity of practice, the data shows that the product is also less in demand. Moreover, practitioners claim that the activities are unworthy in terms of economy (unprofitable).

- Insignificant in community - They asserted that the activity is important to them, or rather very significant in their life. However, the activities appear insignificant to the community life (from the practitioner's perspective). In this regard, it demonstrates an unpleasant fact; whereas in order to ensure viability of the domain, the main factor is that it (the $\mathrm{ICH}$ ) must be treasured by the community as well. The community should feel it is valuable and significant to their life, which in this case, it portrays the opposite.

- Transmission issues - Majority of the practitioners claim that there is no possibility for them to hands down their skills to the next generation. The main reasons that could be enlightening at this section are firstly, the practitioners have no heir, and secondly, their children refused to continue with the activity.

- Capital obstacle - practitioners experience capital obstacle in continuing the activities and claim not receiving any financial aid from any agencies or local authority.

\subsection{Criterion 3 - Identification Potential to Safeguards}

Criterion 3 aimed to identify possibilities of the domain to sustain. The result shows that both domains are valuable and significant to the research area (refer Table 3.3). As the expertise and inheritance are from the ancestors, the activities give an impact towards their life and the identity of the research area as well. However, similar issues as to the viability aspect, is that there are also transmission issues taking place at this point. The findings for criterion 3 are:

Table 3.2 Summary of Frequency Distribution of Viability Measures

\begin{tabular}{llcc}
\hline Viability Measures & \multicolumn{1}{c}{ Domain } & $\begin{array}{c}\text { Traditional craftsmanship } \\
(\mathrm{n} / 19)\end{array}$ & $\begin{array}{c}\text { Knowledge and practice } \\
(\mathrm{n} / 14)\end{array}$ \\
\hline \multirow{2}{*}{ Frequency of practice } & Daily & 6 & 14 \\
& Upon Request & 13 & - \\
\hline Important level for individual & Not important & - & - \\
\hline
\end{tabular}




\begin{tabular}{llcc}
\hline & Slightly important & - & - \\
& Average & 3 & 2 \\
& Important & 16 & 12 \\
\hline \multirow{3}{*}{$\begin{array}{l}\text { Important level for } \\
\text { community }\end{array}$} & Not important & 3 & - \\
& Slightly important & - & 14 \\
& Average & 14 & - \\
\hline \multirow{3}{*}{ Potential to hands down } & Important & 2 & 5 \\
& Nos & 1 & 3 \\
\hline \multirow{2}{*}{$\begin{array}{l}\text { Obstacles in continuing } \\
\text { practices }\end{array}$} & Not sure & 12 & 6 \\
\hline \multirow{2}{*}{ Current efforts to preserve } & Cource & 6 & - \\
& Skiltal & 2 & - \\
\hline
\end{tabular}

- Skilled and Knowledgably Practitioners - Traditional Craftsmanship practitioners undertake because that is their field of expertise. Meanwhile for Knowledge and Practice Domain, hereditary is the main factor of undertaking. Due to these factors, both domains are considered as valuable and significant to the place identity as well.

- Hereditary Significant - The result shows majority (11 practitioners) of the Traditional Craftsmanship are 2nd and 3rd generation. The result is similar to Knowledge and Practice Domain, where all of the respondents are 2nd and 3rd generations inheriting the knowledge from their ancestors.

- Transmission Issue - The practitioners and respondents of both domains are optimists in continuing the practice of the activities. They have no plans to change it. However, the statistics show a very low potential to transmit. As shown in Table 3.4, 12 out of 19 practitioners who are certain that they will not transmit to the next generations, only one (1) practitioner is willing to transmit. The same issues confronted by the second domain in which, 3 out of 5 are hesitant in this matter.

Table 3.3 Summary of Frequency Distribution of Safeguarding Measures

\begin{tabular}{llcc}
\hline Safeguarding Measures & \multicolumn{1}{c}{ Domain } & $\begin{array}{c}\text { Traditional craftsmanship } \\
(\mathrm{n} / 19)\end{array}$ & $\begin{array}{c}\text { Knowledge and practice } \\
(\mathrm{n} / 14)\end{array}$ \\
\hline \multirow{3}{*}{$\begin{array}{l}\text { Reasons for } \\
\text { undertaking }\end{array}$} & $\begin{array}{l}\text { Hereditary } \\
\text { profitable }\end{array}$ & 7 & 14 \\
& Interest and & - & - \\
& hobby & 1 & - \\
\hline \multirow{3}{*}{ Hereditary generations } & Expertise & 11 & - \\
& 1 & 8 & 8 \\
& 2 & 8 & 6 \\
\hline
\end{tabular}


Mohd Rodzi, N.I., et.al., / Asian Journal of Behavioural Studies, AjBeS 1(4), Nov. / Dec. 2016 (p.45-55)

\begin{tabular}{llcc}
\hline \multirow{3}{*}{ Plan to change } & Yes & 3 & - \\
& No & 15 & 14 \\
& Not sure & 1 & 5 \\
\multirow{2}{*}{ Potential To Hands } & Yes & 1 & 3 \\
Down & No & 12 & 6 \\
\hline
\end{tabular}

\subsection{Criterion 4 - Local Community Awareness}

According to criterion 4, if the state party intends to nominate the element in the Urgent Safeguarding List, the nomination must involve the community, group or individuals. The community, group or individuals should perceive and agree on the nomination of the elements. Accordingly, this point is to discover the awareness of the community on $\mathrm{ICH}$ elements. From the 599 occupied building, only 399 (49\%) of the community are willing to participate in questionnaire survey, $200(24.5 \%)$ refused.

The first measurement was to discover ICH understanding among the community. This part also attempts to explore the community's perception on $\mathrm{ICH}$ aspect and elements. Forty-five (45) or $11.3 \%$ out of 399 respondents understand the scopes of $\mathrm{ICH}$. Nevertheless, majority does not know or are familiar with the ICH aspect and elements. In the second measures, the study found that $53(13.3 \%)$ of the respondents were able to illustrate ICH elements. However, the other respondents (346 or $86.7 \%$ ) could not explain it. As a third measure, the respondents were requested to identify any $\mathrm{ICH}$ that subsists in the research area. The result shows that $344(86.2 \%)$ of respondents did not perceived any local ICH in the research area. However, $32(8 \%)$ of them considered the Baba Nyonya culture as $\mathrm{ICH}$ element. Thirteen (13) or $3.3 \%$ of the respondents declare that $\mathrm{ICH}$ in the research area is the living heritage and $10(2.5 \%)$ of the respondents illustrate traditional craftsmanship as $\mathrm{ICH}$ element.

The last measure was to explore community's awareness on Melaka receiving UNESCO recognition. There are $218(54.6 \%)$ from 399 respondents believe that the factor of the recognition is $\mathrm{TH}$, which means the architecture of buildings in the area. In addition, $141(35.3 \%)$ of respondents do not know what contributed to the recognition. The result also appears that $38(9.5 \%)$ of respondents believe it is because of both $\mathrm{TH}$ and $\mathrm{ICH}$, and only $2(.5 \%)$ respondents think that it is due to the unique $\mathrm{ICH}$ in the area that contributed to the nomination. (Refer Table 3.4)

Table 3.4 Summary of Frequency Distribution on Local Community Awareness

\begin{tabular}{|c|c|c|}
\hline Awareness elements & & Total \\
\hline \multirow{3}{*}{ ICH Understanding } & Yes & $45(11.3 \%)$ \\
\hline & No & $354(88.7 \%)$ \\
\hline & Yes & $53(13.3 \%)$ \\
\hline \multirow[t]{2}{*}{ ICH Identification } & No & $346(86.7 \%)$ \\
\hline & Living Heritage & $\begin{array}{r}13 \\
(3.3 \%)\end{array}$ \\
\hline Identification of Local ICH & Traditional Craftsmanship & 10 \\
\hline
\end{tabular}


Mohd Rodzi, N.I., et.al., / Asian Journal of Behavioural Studies, AjBeS 1(4), Nov. / Dec. 2016 (p.45-55)

\begin{tabular}{lrr}
\hline & & $(2.5 \%)$ \\
\cline { 2 - 3 } & Cultural of Baba and Nyonya & 32 \\
& & $(8 \%)$ \\
\cline { 2 - 3 } & Don't know & $344(86.2 \%)$ \\
\cline { 2 - 3 } Reason of UNESCO Recognition & Tangible cultural heritage & $218(54.6 \%)$ \\
\cline { 2 - 3 } & Intangible cultural heritage & 2 \\
& & $(0.5 \%)$ \\
\cline { 2 - 3 } & Tangible and intangible cultural heritage & 38 \\
& & $(9.5 \%)$ \\
\cline { 2 - 3 } & Don't know & $141(35.3 \%)$ \\
\hline
\end{tabular}

\subsection{Criterion 5 - Role of State Parties}

To respond to the Criterion 5, researchers targeted three (3) State Parties that are responsible within the research area as respondents. There were three (3) questions framed by researchers, the questions focussed on; 1) necessary and safeguarding measures, 2) inventory, and 3) current safeguarding effort. The results are presented as below:

- Necessary and safeguarding measures

The respondents have similar thoughts in "safeguarding measure". They claim that they refer to the policies and regulations. There are three (3) regulations currently applied to the research area, which are the National Heritage Act (2005) as the highest level of legislation; the Town Planning Act (act 172); and Melaka Enactment 1988, that upholds to the National Heritage Act (2005) pertaining to ICH safeguarding.

- Inventory

Article 12 has underlined the required documentation for $\mathrm{ICH}$ by the states parties. Documentation is considered as one of the efforts to ensure the originality of identified local $\mathrm{ICH}$ recorded. Nevertheless, through the interview, it shows that there is no specific inventory of local ICH (within the case study area) prepared by any agencies.

- Current safeguarding effort

As the safeguarding measure and inventories are considered mandatory to the states parties, their current effort should also be taken into account. A good effort from each agency somehow will enhance survival rate of the $\mathrm{ICH}$ value. All of these agencies have been organising programs such as workshop and course. These programs are an effort to boost awareness level instead of relying on policies and act since they do believe that knowledge and understanding of the society is very important.

\subsection{Discussions}

\subsection{Research Findings}

The major findings are: 1) Three (3) major domains of $\mathrm{ICH}$ subsist; 2) The viability of dominant $\mathrm{ICH}$ is weak; 3) The dominant $\mathrm{ICH}$ has low potential to be safeguarded; 4) 
Minimal awareness and understanding on $\mathrm{ICH}$ by the local community; and 5) Dominant ICH has not established within the core zone territory (Refer Table 4.1).

Table 4.1 Summary of Research Findings

\begin{tabular}{|c|c|c|}
\hline Criterion & \multicolumn{2}{|l|}{ Findings } \\
\hline \multirow{4}{*}{ Criterion 1} & \multicolumn{2}{|c|}{3 major domain of ICH subsist; } \\
\hline & \multicolumn{2}{|c|}{$\begin{array}{l}\text { 1. Traditional craftsmanship domain } \\
>\text { Identified } 20 \text { practitioners in } 2013,2 \text { practitioners passed away in } 2015\end{array}$} \\
\hline & \multicolumn{2}{|c|}{$\begin{array}{l}\text { 2. Social ritual, practices and festive domain } \\
>22 \text { religious and association buildings }\end{array}$} \\
\hline & \multicolumn{2}{|c|}{$\begin{array}{l}\text { 3. Knowledge and Practice Concerning Nature and Universe Domain } \\
>14 \text { traditional trades significant to past function of the Kg. Pantai Street }\end{array}$} \\
\hline \multirow{6}{*}{ Criterion 2} & \multirow[t]{5}{*}{5 major issues } & 1. Irregularity in practicing \\
\hline & & 2. Lack of demand and unprofitable product \\
\hline & & 3. Insignificant to the community \\
\hline & & 4. Transmission issues \\
\hline & & 5. Capital obstacle \\
\hline & Major finding & Weak viability level \\
\hline \multirow{4}{*}{ Criterion 3} & \multirow[t]{3}{*}{3 findings } & 1. Skilled and knowledgeable practitioners \\
\hline & & 2. Hereditary significant \\
\hline & & 3. Transmission issues \\
\hline & Major Finding & Low potential to safeguards \\
\hline Criterion 4 & \multicolumn{2}{|c|}{ Local community lacks awareness and understanding } \\
\hline Criterion 5 & \multicolumn{2}{|c|}{$\begin{array}{l}\text { There is no specific inventory, policy, standard or regulation for ICH. } \\
\text { Dominant ICH has not established within the core zone territory. }\end{array}$} \\
\hline
\end{tabular}

\subsection{Status of ICH in Melaka World Heritage Site}

Table 4.2 shows the summary of all criterions. To evaluate the status of $\mathrm{ICH}$ in the research area, researcher sets up weights for each measurement of the criterions. There are three (3) stages of weight in the Quantitative Analysis. The weights are: 1) when the frequency of the measurement show below $50 \%$, it is considered as negative influence, thus the weight is one (1);2) If the statistic shows precisely $50 \%$, its considered average, therefore, the weight score is 2.5 and 3) weight five (5) is for statistic that is over $50 \%$, as it is considered as positive influence. Weights for Qualitative Analysis are also classified into three (3): 1) if majority of feedback is positive, it is marked as five (5), 2) If the majority of responses demonstrate as average, the weight is 2.5 , and 3 ) if outcome illustrated negative influence then the weight, it is marked as one (1). Table 3.6 shows the total score is 44.5 I 110 , which is less than half of the total marks to be considered as average (the average score is 55). Thus, the findings suggest the ICH in the Melaka World Heritage Site (MWHS) can be declared as threatened

Table 4.2 Summary of Criterions

\begin{tabular}{llc}
\hline Criterion & Description & Weight \\
\hline Criterion 1 & Oral traditions and expressions & - \\
& Performing Arts & -
\end{tabular}




\begin{tabular}{llc} 
& Social Practices, rituals and festive events & 5 \\
& Knowledge and practices concerning nature and the & 5 \\
& universe; & 5 \\
& Traditional Craftsmanship & 1 \\
& Frequency Of Practice & 5 \\
& Important Level For Individual & 2.5 \\
& Important Level For Community & 1 \\
& Potential To Hands Down & 1 \\
& Obstacles In Continuing Practices & 1 \\
\hline Criterion 3 & Current Efforts To Preserve & 2.5 \\
& Reason for undertaking & 5 \\
& Hereditary generations & 1 \\
& Plan to change & 1 \\
\hline Criterion 4 & Potential To Hands Down & 1 \\
& ICH understanding & 1 \\
& ICH identification & 1 \\
& Identification of ICH in Territory & 1 \\
\hline Criterion 5 & Awareness & 2.5 \\
& Necessary and safeguarding measure & 1 \\
& inventories & 1 \\
\hline Total Score & Current effort & 44.5 \\
\hline
\end{tabular}

Notes:

For quantitative analysis;

i) Statistic shows $50 \%>=5$

ii) Statistic shows $50 \%=2.5$

iii) Statistic shows $<50 \%=1$
For qualitative analysis;

i) Positive view/feedback/influence $=5$

ii) average view/feedback/influence $=2.5$

iii) Negative view/feedback/influence $=1$

\section{0 Recommendation}

The threat to the $\mathrm{ICH}$ in the Melaka World Heritage Site (MWHS) is rather worrying, when enforcement and effort by state parties to safeguard the $\mathrm{ICH}$ is still in infancy. In order to mitigate these issues, the state parties are recommended two pursue (2) aspects.

The first aspect is to strengthen the level of awareness and understandings in the $\mathrm{ICH}$ by establishing the dominant ICH in the Core Zone area. Agencies can set up research and development (R\&D) unit that focuses on the $\mathrm{ICH}$ within their territory. The second aspect is to improve the management and safeguarding efforts. This can be done by establishing specific policies and regulation for the $\mathrm{ICH}$ in the Core Zone area. Involvement of the community in cultural heritage management is vital and their opinions should be considered in the process of heritage protection. The state parties are also encouraged to collaborate with the community to create apprentice of the related ICH skills and knowledge.

It is suggested that further researches need to concentrate on the investigation of challenges confronted by state parties in safeguarding $\mathrm{ICH}$, and develop a proposed database of dominant ICH in MWHS. 


\section{References}

Bakar, A. A., Mariana, M. O., Syahriah, B., \& Mansor, I. (2014). Analysis on Community Involvment Level in Intangible Cultural Heritage: Malacca cultural community. Procedia-Social Behavioral Sciences , 286-297.

Bouchenaki, M. (2003). The interdependency of the tangible and intangible cultural heritage. Zimbabwe: ICOMOS.

CAPAM. (2010). Overview of Case Study Models and Methodology. Ottawa: Commonwelth Association for Public Administration and Management.

Congdon, J. D., \& Dunham, A. E. (1999). Defining the Begining: the importance of research design. In K. L. Eckert, K. A. Bjorndal, F. A. Grobois, \& F. Donelly, Research and management techniques for the conservation of sea turtles (pp. 83-87). Washington: IUCN/SSC Marine Turtle Specialist Group Publication.

ICOMOS. (2008). Evaluations of Cultural Poperties . Canada : UNESCO.

Johnson, R. B., Onwuegbuzie, A. J., \& Turner, L. A. (2007). Toward a Definition of Mixed Methods Research . Journal of Mixed Methods Reseach, 112-133.

Munjeri, D. (2004). Tangible and Intangible Heriatge: from difference to covergence. Museum International , 13-20.

Othman, R. N., \& Hamzah, A. (2013). Interdependency of Cultural Heritage Assetes in Old Quater, Melaka Heritage City. Procedia-Social and Behavioral Sciences, 577-588.

Powell, E. T., \& Steele, S. (n.d.). Collecting evalutaion Data: Direct Observation. Retrieved May 14, 2014, from http://learningstore.uwex.edu/assets/pdfs/g3658-5.pdf

Remenyi, D. (2011). Field methods for academic research - interviews, focus group and questionnaires. united Kingdom : Ridgeway Press .

Simon, M. K., \& Goes, J. (n.d.). Scope, limitations and delimitations. Retrieved January 13, 2013, from www.dissertationrecipes.com

Szolnoki, G., \& Hoffman, D. (2013). Online, Face - to - face and telephone surveys : Comparing different sampling methods in wine consumer research. Wine Economy and policy $2,57-66$.

UNESCO. (2009). List of Intangible in Need of Urgent Safeguarding. Canada: UNESCO. 